\title{
Materials for the intervention of construction systems for adobe housing
}

\section{Materiales para la intervención de los sistemas constructivos para vivienda de adobe}

CASTILLO-REYES, Alberto Rosendo $\dagger^{*}$, VÁZQUEZ-TORRES, María del Rayo, MORALESORTEGA, Alejandro and MONTERO-URRUSQUIETA, Rubén Ángel

Benemérita Universidad Autónoma de Puebla, Mexico.

ID $1^{\text {st }}$ Author: Alberto Rosendo, Castillo-Reyes / ORC ID: 0000-0001-6338-2534, Researcher ID Thomson: U-9440-

2018, CVU CONACYT ID: 950754

ID $1^{\text {st }}$ Coauthor: María del Rayo, Vázquez-Torres / ORC ID: 0000-0002-3509-2684, Researcher ID Thomson: U-85612018, CVU CONACYT ID: 508248

ID $2^{\text {nd }}$ Coauthor: José Alejandro, Morales-Ortega / ORC ID: 0000-0001-8379-4405, CVU CONACYT ID: 659620

ID $3^{\text {rd }}$ Coauthor: Rubén Ángel, Montero-Urrusquieta / ORC ID: 0000-0001-6325-2238, CVU CONACYT ID: 599097

\begin{abstract}
This research aims to identify the relationship between the deterioration of constructions and restoration systems that will allow their permanence. The method applied to this research is qualitative in nature to publicize the maintenance systems that will allow the recovery of adobe constructions and recognize the technical richness. Qualitative research allows us to establish the observations of the social world, considering the experiences of the community, so that they can obtain information about their values, experiences, practices, customs and traditions. All this to come to issue solutions that do not attack your social environment and your urban image. The stages of the research were: fieldwork linking access to the field with productive data collection; data analysis in a continuous review that consisted of reducing information, disposition, transformation and obtaining results and verifying them to reach conclusions. Finally, the preparation of the report generated various approaches, and one of them produced the theme of this work whose contribution is that it identifies the constructive systems that can serve to generate new lines of research to promote the conservation of traditional architecture.
\end{abstract}

\begin{abstract}
Resumen
Esta investigación tiene como objetivo, identificar la relación que existe entre el deterioro de las construcciones y los sistemas de restauración que permitirán su permanencia. El método aplicado a esta investigación es de carácter cualitativo para dar a conocer los sistemas de mantenimiento que permitirá la recuperación de las construcciones de adobe y reconoce la riqueza técnica. La investigación cualitativa, permite establecer las observaciones del mundo social, considerando las experiencias de la comunidad, para que permitan obtener información sobre sus valores, experiencias, prácticas, costumbres y tradiciones. Todo esto para llegar a emitir soluciones que no agredan a su entorno social y a su imagen urbana. Las etapas de la investigación fueron: el trabajo de campo relacionando el acceso al campo con la recolección productiva de datos; el análisis de datos en una continua revisión que consistió en reducir la información, disposición, transformación y la obtención de resultados y verificación de estos para llegar a conclusiones. Por último, la elaboración del informe generó diversos enfoques, y uno de ellos produjo el tema de este trabajo cuya contribución es que identifica los sistemas constructivos que pueden servir para generar nuevas líneas de investigación para favorecer a la conservación de la arquitectura tradicional.
\end{abstract}

Vivienda, Sismos, Rehabilitación

\footnotetext{
* Correspondence to Author (Email: arcastillor@gmaill.com)

$\dagger$ Researcher contributing as first author.
} 


\section{Introduction}

A construction system is the set of procedures that contemplate the materials, techniques and tools that intervene in its elaboration. All materials have a shelf life; understanding utility to the duration of an object that allows to exercise the function for which it was designed or elaborated. The duration of the materials of the buildings is a little known topic, in addition, the existing works are focused on materials such as concrete and steel, but not on the area of earth materials. This is due to the fact that earth materials do not have standardized conditions, since their resistance depends on the mineralogical characteristics of the place where the raw material is obtained. Also the weather conditions of the area where the building is located that causes deterioration of the property. Deterioration is described as decline, a principle of weakness that leads to destruction or disintegration. It has become synonymous with the concept of decay or destruction of systems that, when interacting with each other, cause an imbalance. In the field of architecture for Juárez, Gómez, \& Sordo (2002) deterioration is a factor that affects the structural behavior, especially in adobe constructions and their roof systems. All this is caused by the structural behavior, the useful life of the materials and the climatic conditions such as humidity and humidity because it compromises the structural behavior in the event of earthquakes as it increases its vulnerability.

The deterioration of the materials modifies the conditions of the structural behavior, both in the adobe walls and in the roof, by the junction between wall and roof or by the conditions of the beams, although they have a healthy appearance, they can be rotten inside. cause of fungus or moisture. Sunlight and humidity cause dimensional alterations of the materials and especially of the adobe as it can cause its pulverization. These conditions weaken the sections of the house and when there is an earthquake, the house or part of it may crack or collapse.

For these reasons, adobe constructions can be totally or partially affected. The latter causes the construction to be intervened constructively; understanding the concept of intervention as the set of actions that are applied to a building to restore the original conditions of its elements so that it recovers its function.
Considering all the above, this work is divided into 3 sections: characteristics of the house, the structural system and the intervention materials. In the housing characteristics section, the elements that compose it and the problems they may have are addressed. The rehabilitation section establishes the basic conditions of these institutions for the rehabilitation of buildings and the intervention materials section explains the most common and least invasive systems for the rehabilitation of adobe houses.

\section{Characteristics of the property}

Adobe is one of the important materials in traditional architecture around the world and in Mexico there is still a great construction tradition on this material. In the ICOMOS WORLD REPORT 2006/2007 report (Guerrero, 2008). The importance of adobe in Mexico is manifested as a basic building material, as a highly efficient material for the management of natural resources and its application in architecture, taking advantage of its thermal characteristics and as a material that is part of the cultural heritage.

The report also establishes that adobe is disappearing throughout Mexico, but indicates two important regions for the valuation of the Cultural Heritage of Humanity: Paquimé, in the state of Chihuahua, north of Mexico and the region linked to the Popocatépetl volcano, in the center of Mexico. Paquime, a pre-Hispanic city called the Casas Grandes Archaeological Zone (10th to 15th centuries), disappeared during the Spanish conquest and inscribed on the World Heritage list in 1998. The Popocatépetl area is located within the territorial limits of the states of Morelos, Puebla and the state of Mexico.

The latter is relevant because in these states of the Mexican Republic there are still areas with adobe architecture that must be intervened due to the effects of natural conditions and seismic events. In rural areas of the Mexican Republic, adobe constructions are common structures, with different structural characteristics and in some cases with elements that improve structural behavior. Adobe buildings or houses are spaces with variable dimensions, but the maximum dimensions are 8 $\mathrm{m} \mathrm{x} 4 \mathrm{~m}$. The roof system is generally made of wood composed of a wooden beam, arranged in the long sense and secondary beams in the short sense. 
They are generally single-slope and gabled constructions. When they are 2 waters, the roof system has wooden trusses that are not enough to transmit the weight of the roof system perimeter, causing the weight to not be distributed over the 4 walls causes instability in the face of horizontal loads and stress concentrations or faults in the corners of walls, or bending. In adobe houses, it is common to see buildings without windows or with $0.40 \times 0.40$ $\mathrm{m}$ windows. without exceeding $0.60 \times 0.60 \mathrm{~m}$., because it is an unfavorable condition due to the concentration of efforts, which can cause shear or bending cracks in the walls. The way to ventilate is to leave the door open, remove some beams or make small holes in the wall. To reinforce the walls in some communities they place wooden lintels, and sometimes, these lintels have them on the peripheries of the openings, improving the behavior of these constructions (Juárez, Gómez, \& Sordo, 2002).

These characteristics are observed in the area of the Popocatépetl volcano, the houses lack windows or have small windows no more than $0.40 \mathrm{~m}$. and a door no more than $1 \mathrm{~m}$. as there is a concentration of stresses, which produce shear or bending cracks in the walls. It is for this reason that wooden lintels are included to achieve stability in the openings. After the earthquake of 2017, the inhabitants in their eagerness to obtain security in their constructions placed dalas and castles on the edges of doors and windows, although it is a practical solution, it is highly invasive.

The roofing material can be overlapping tiles, wood and sheets of different types. It is common to see cracks and even collapse due to lack of connection and dimensional variation caused by changes in atmospheric temperature. Above all, in materials where there are breaks, cracks or fissures and detachments, caused by an external action, where the fragility of the wall intervenes in which a load is applied that causes an exaggerated deformation. Adobe absorbs atmospheric moisture and loses its resistance to stress, a situation that is increased by changes in the temperature of the material.
The causes of the disappearance of adobe architecture are varied, but one of those causes is the damage to adobe houses that have suffered from the effects of earthquakes and the problem is not only in the choice of materials, but also in the lack of foundations, lack of supervision in construction and / or poor construction techniques, in placing new rooms on top of the houses. Another cause of adobe is its vulnerability to natural elements, which favors the deterioration of the home, especially the relative humidity inside the walls that favors the rotting of the wooden elements that are supported by the adobe. (Gisbert Nieto, A., 2020).

To prevent moisture in the basements, a baseboard or foundation is placed, although as it may be that in sloping areas the foundation is insufficient and allows the absorption of water from the soil.

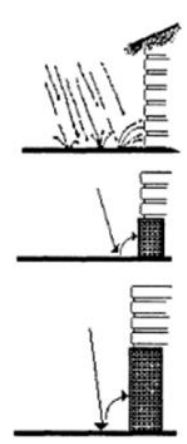

Figure 1 The action of rainwater on the base of the wall is shown

Source: (Peña, 1997, p. 64)

In Tochimilco, Puebla, a place in the Popocatépetl Volcano area, the roofs are sloped from $11 \%$ to $45 \%$ slope; However, towards the facade the highest part of the wall is placed, making it appear from the facade that they are horizontal ceilings. That is why there are humidity problems due to the connection because the roof is attached to the wall and it does not have an eaves (houses that the facade faces the street) since the eaves are not enough to protect the union of the wall and the beams or when the eaves is not enough to contain the rain and moistens the basement. 

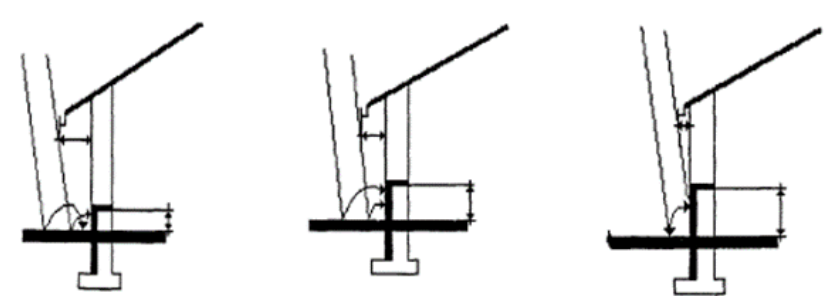

Figure 2 Moisture in the basements on roofs with eaves. Action of rainwater in buildings with eaves on the base of the wall

Source: (Peña, 1997, p. 65)

It should be clarified that in the case of openings in doors, windows and element joints, there may be water seepage due to the separation of the materials and its consequent degradation. As well as the vulnerability when doors exceed $1 / 3$ of the total length of the wall or when there are openings with little separation, because the transmission of the weight of the roof can cause cracks in the jambs of historic houses. The lengths of the spans must not exceed $1 / 3$ of the total length and if there are more than one opening they must be evenly distributed and separated (not less than $0.65 \mathrm{~m}$ ) from the corner at least $1.00 \mathrm{~m}$.

In the case of the foundation, there are different problems that affect the building, such as the rocks that make up the foundation leave holes where there is no mortar to unify the masonry. The overlay is recommended that protects the adobe or brick wall or the humidity caused by the absorption of the soil, the dripping of the roof and the impact of water by rain or by human actions. The foundations in Tochimilco have a height of 0.50 to 0.80 meters, but due to the topography of the place they can be greater and even disappear.

\begin{tabular}{|c|c|c|c|c|}
\hline \multirow{2}{*}{$\begin{array}{l}\text { Minimum } \\
\text { values }\end{array}$} & \multicolumn{4}{|c|}{ Over foundation height } \\
\hline & $25 \mathrm{~cm}$. & $35 \mathrm{~cm}$. & $55 \mathrm{~cm}$. & Observations \\
\hline features & $\begin{array}{l}\text { Dry region } 450 \\
\text { mm of rain per } \\
\text { year. } \\
\text { Construction } \\
\text { with large } \\
\text { eaves. }\end{array}$ & $\begin{array}{l}\text { Normal } \\
\text { rainfall }\end{array}$ & $\begin{array}{l}\text { Rainy } \\
\text { region } \\
\text { with } \\
\text { narrow } \\
\text { eaves. }\end{array}$ & $\begin{array}{l}\text { Consider the } \\
\text { direction of the } \\
\text { water: a height } \\
\text { between } 15 \text { and } 50 \\
\mathrm{~cm} \text { and in rooms } \\
\text { with a high risk of } \\
\text { humidity, require a } \\
\text { greater height. }\end{array}$ \\
\hline
\end{tabular}

Table 1 The minimum heights of the basements are shown Source: Vázquez 2019 with information from Peña, 1997

Rainwater is absorbed by the adobe; However, currently the action of man when using vehicles is similar to a torrential because it expands the water under pressure over a large area of the wall.
One way to reduce the amount of rainwater to the walls when the eaves are not made, is through gutters that collect the water to certain points, in which they are received by vertical tubes called downspouts. The gutters can be of semicircular section, which are suspended on the front edge of the ailerons, or boxes that are supported. The gutters are supported by fixing hooks that have freedom of movement to expand and contract, taking care that the wall covering must be 4 to $5 \mathrm{~cm}$ due to the less favorable conditions of work on site (Lefevre \& Lilian, 2016).

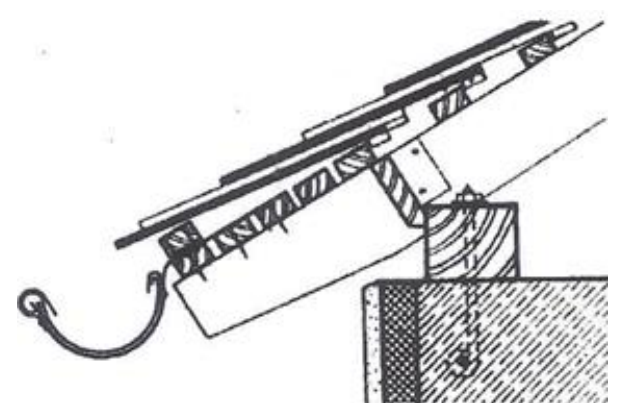

Figure 3 Gutter

Source: (Lefevre \& Lilian, 2016)

In Tochimilco this is a cause that is affecting homes in some areas where the sidewalk is $0.40 \mathrm{~m}$ wide. that allows water to permeate the internal area of the walls and later fluorescence develops that erode the adobe. In addition, placing pluvial installations such as pergolas, pipes that cross the foundation or electrical installations that modify the composition of the wall.

Regarding the enclosures on doors and windows of the vernacular house, the efficiency of wooden lintels that lean at least 40 centimeters to the wall has been proven, it must be taken care that the wood is completely dry since it has been observed in new constructions in Tochimilco that the wood when receiving the weight of the wall and the ceiling flexes. In the case of historical houses, wooden lintels have also been used, but partition lintels are observed in lowered and semicircular arches.

It is important to note that in the earthquake of September 19, 2017, it was observed in the adobe houses that the collapsed roofs had beams with smaller dimensions, humid, with fungi, separations greater than 0.50 $\mathrm{m}$ or there were no beams because the damaged beams were not replaced. or they were eliminated to leave the passage of facilities. 
The corner joints are diagonal wooden elements that join the beams allowing greater stability of the ceilings. When placing the sheet, care must be taken that the overlap coincides with a beam to fix it with screws with washers and rubber or long nails so that it penetrates the wood at least $5 \mathrm{~cm}$.

It should be noted that in Mexico there is a great experience on the conservation of the built heritage, but in the case of the rehabilitation of the vernacular adobe house, many techniques cannot be applied because these houses must be restored quickly because their inhabitants do not have other spaces where to live. Furthermore, the available resources are often insufficient to carry out a reliable, economical and safe intervention.

\section{Rehabilitation}

Although the use of adobe exists in other parts of Mexico, the Public Administration of Mexico City (2017) and ONNCCE (2015) do not include this material within their quality standards, but the basic conditions of these institutions for the rehabilitation of buildings, where, it is required the shoring, temporary rehabilitation and demolition; as well as access control considering the following:

When there is damage to the structure that could endanger its stability, access will be controlled and temporary support and rehabilitation will have to be done while the evaluation is being made. It is important to provide the temporary stiffness and resistance for the safety of the workers working in the building, neighbors and pedestrians in the adjacent areas. Temporary rehabilitation also applies when modifications are made to a structure that imply a temporary decrease in the stiffness or resistance capacity of some structural element. The construction will be demolished in the event that there is a risk of partial or total collapse, risk to neighboring buildings or communication routes.

Safety during rehabilitation must guarantee the stability of the structure, for which it must be demonstrated that the building has the capacity to simultaneously withstand the estimated vertical actions (dead and live loads) and $30 \%$ of the accidental ones contained in the Complementary Technical Standards.
For Design by Earthquake. The connection between existing elements and new materials or elements must be designed and executed in such a way that they can achieve monolithic behavior and ensure the transmission of forces from the elements.

Also, it is considered that any material, traditional or current, impacts the environment, but the advantage of adobe is that the energy consumption of construction is almost nonexistent, since it is a material that is found almost anywhere and once its cycle of Life ends can return to the natural environment (Ramírez M. Á. 2011).

The structural system used for adobe construction presents difficulties in linking the foundation and roof elements with the transverse and longitudinal walls. This situation occurs due to the thickness of the walls and their poor adherence and their reduced range of elastic behavior; Achieving with this material a structural system that complies with the current earthquake resistant design philosophy is almost impossible. The reduced range of elastic behavior means that the deformations caused by very low forces affect the adobe walls and severely damage them. However, in adobe constructions that have survived over time in seismic zones, with walls of considerable thickness they still remain, but this is due to massiveness, since adobe as a whole presents a value close to $10 \%$ of the capacity. compression of the system that allowed it to resist by gravity the possibility of overturning by wind forces and the loss of resistance due to weathering (González, Aguilar, \& Gómez, 2008).

For historic and adobe buildings, materials that present compatibility problems such as block and partition are applied; In addition, metallic and carbon materials corrode with loss of their physical, chemical and reinforcing element characteristics.

To intervene in a building, the materials used must be considered, as they must cover the durability and chemical, physical and mechanical compatibility of the original materials; Therefore, it is convenient to use traditional materials for its restoration (Peña \& Lourenço, 2012). 
Regarding the problems of degradation of buildings, they cause the need for their maintenance and restitution, for which it should be noted that any reinforcement technique causes loss of cultural value. Each reinforcement technique must be analyzed as some techniques are highly invasive; however, these are used when the problem is the reduction of seismic effects.

For adobe buildings in rural seismic areas, due to the ease of acquiring the materials, wood reinforcements, mortar mesh and reinforced concrete elements have been used These techniques are invasive, however, confinement woods improve the behavior of the walls of adobe before the seismic effects. In the case of reinforced concrete elements, they architecturally modify the construction and the soluble salts contained in Portland cement, the crystallization of which is expansive and due to mechanical phenomena that cause deformations. It is important to note that if tension stresses are reduced, the behavior of earthen walls can be substantially improved (López Pérez, et al., 2007).

According to (González, Aguilar, \& Gómez (2008), the techniques of damage repair and structural rehabilitation in adobe houses used in Mexico and abroad are a function of the economy and lately, it has become from the point of view of sustainability and its attractive presentation for the architectural project.

According to Peña \& Lourenço (2012), the following conditions are established for intervention in buildings: respect for structural authenticity, minimal alteration or impact and structural safety, compatibility, interventions that contribute to preserving integrity, reversibility and removal and monitoring.

Respect for structural authenticity refers to the fact that the property is part of its cultural value, so it is necessary to preserve both the original system and its materials as long as they provide an adequate level of security favoring the minimum alteration or impact. Structural safety is a very important issue because the building can experience structural damage that endangers the lives of the people who inhabit it, in many cases it is affected by the incompatibility of materials or construction systems for which it is necessary choose the technique that presents minimal invasion.
Compatibility refers to the fact that the materials and technical devices used for repair or reinforcement must be compatible with the originals; Old materials should be chemically compatible with new materials, and new materials should not experience chemical or physical phenomena that could cause any damage to existing materials. Whenever possible, the measures taken should be reversible for that when dismantled. The original material or the structure returns to the previous state without suffering damage or permanent deterioration to open the possibility of replacing or changing, in the future, the reinforcement for a more suitable or effective one.

All the above must be controlled during its execution, so as not to allow actions that are impossible to control. A supervision and control program must accompany any intervention proposal, to avoid damaging the structure during the intervention works.

From the above, it follows the following conditions defined by Peña and Loureco (2012) to establish the intervention plans, which are the acquisition of data, structural behavior, diagnosis and safety measures and intervention materials that are described below.

The historical information will allow us to understand the structural behavior over time and its behavior in the face of earthquakes, differential subsidence, hurricanes, etc. As well as the damages presented and the different repairs that the building has undergone. The structural geometry of historical buildings is quite complex, preliminary studies are recommended for the characterization of materials and detection of damage with sonic techniques, radar, thermography, environmental vibration, flat jacks, etc.

Simplified methods of analysis are highly effective for the analysis of this type of historical structures. The use of two or more analysis tools allows to overcome the complexity of the seismic behavior of old masonry structures. The evaluation of the structural safety of a historic building should not be based solely on the quantitative study, but also on the evidence about the behavior of the building in the face of past events (qualitative study), that is, based on its own history. 
All this will allow the intervention measures to be based on the causes of the problem and the intervention must be based on the safety criteria, keeping the intervention to the minimum possible to guarantee the safety and durability of the structure with the minimum possible damage to the values. of the building.

The term intervention is related to the word rehabilitation that is defined as an improvement in the conditions or its characteristics of the construction. The concept of rehabilitation refers to the actions that are related to consolidations, substitutions and new technological or material elements with new intervention techniques.

The intervention techniques must favor the prior containment of the external actions that cause the pathological process and thus correct from the origin of the failure, being able to place a new structure, reinforcements, and even assess the demolition and replacement and in each of them , the different variants (Monjo \& Maldonado, 2001).

However, the most common problems in adobe homes are the dimensional variations of the adobe, which are defined by the height of the courses since, due to the variable shape of the block, it is necessary to increase the thickness of the mortar joint, making it a less resistant wall. compression.

After a review of the possible intervention techniques in vernacular dwellings, it was observed that the most used techniques to increase their resistance or to repair the system that has failed are the application of a mortar, insertion of wooden beams, placement of reinforced steel, longitudinal tensioners, system modification, wall cladding, material change, increase in transverse stiffness and different types of reinforcements. These intervention techniques analyzed by Díaz, (2007) are defined below.

The application of a mortar of mud, lime, straw and sand allows to increase the adhesion between pieces and the shear resistance of the walls. The insertion of wooden perimeter confinement beams at the junction of the walls with the roof favors structural integrity.
The placement of reinforced steel in horizontal joints as tensioners without cuts up to the vertical elements are used to increase the tensile strength and ductility of the wall. Longitudinal tensioners are used to join longitudinal walls with transverse ones, as well as the roof trusses. Modifying the flexible diaphragm system to confined with chains and concrete castles enhances strength but is highly invasive. Wall cladding with 10-gauge welded mesh, or 20-gauge chicken wire, significantly increases ductility but does not increase strength and stiffness. In addition, the mesh helps as long as it is not in the entire element so that they allow the wall to breathe, because otherwise the water contained in it will end up destroying the wall from the inside out.

Regarding the change of roofing material to reduce weight, replacing clay tile roofs with galvanized sheets, corrugated asbestos or any light material, although the integrity of the floor systems and their connection with the walls. The increase in the transverse rigidity of the system is achieved by annexing internal walls or external buttresses to avoid torsional asymmetries, this modifies the architectural configuration.

Regarding the reinforcements, they can be placed in the adobe pieces with sugar cane fibers to increase the tensile strength, place guadua or cane bars inside, as well as plastic strapping or plastic meshes transversely along of the wall, making a shear envelope, increases the ductility, but not the resistance and rigidity.

A technique used to rehabilitate homes with adobe walls reinforced with geogrid. Bricks without pre-compression tend to fail at small lateral loads as opposed to compacted adobe blocks as they increase density and improve compression stiffness. The mortar to join adobes must present something more of quality than the bricks and without aggregates. The vertical and horizontal joints will have a thickness of approximately $1 \mathrm{~cm}$. The process to raise the wall begins with the placement of the teachers, setting the adobes level on a $1 \mathrm{~cm}$ mud mortar. Subsequently, the course is aligned by tying a raffia string between adobes and the first course is completed. For the rest of the courses, the area of the adobe is pre-moistened for better adherence between consecutive rows. 
All courses should be interspersed with the adobe position between consecutive courses to improve overall performance. Geogrid is a polymeric material that improves the structural behavior of adobe as it acts as the tensile reinforcement of reinforced concrete constructions, absorbing the tensile stresses in the constructive element. In the event of an earthquake, the geogrid prevents the collapse of the structure, although this does not mean that the walls are damaged and require their replacement, since the building could be irreversibly damaged, but the geogrid must prevent its collapse. The geogrid must be placed on both sides of the wall and overlapping each other at least $15 \mathrm{~cm}$ between both sides, taking care of the correct tie in the connection of both meshes by means of raffia ropes. The main characteristic is its high tensile strength that enables the whole to support dynamic loads, which is why it can be placed in new or old constructions as it integrates with the material in the walls without affecting the foundations (Astorga, 2011).

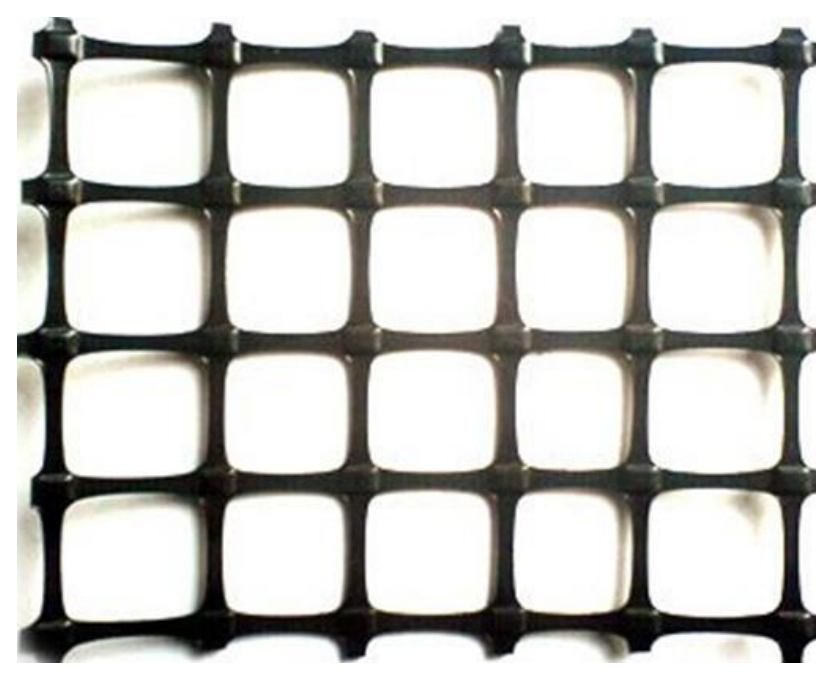

Figure 4 Geogrid, maximum separation of $5 \mathrm{~cm}$ and maximum elongation of $2 \%$ and it is a composite material consisting of an open mesh, which is filled with other materials, increasing the rigidity of the set of great flexibility and resistance to ultraviolet rays. deformation, durability, high corrosion resistance at low cost

Source: (Astorga, 2011)

Below are some intervention systems in adobe homes, starting with those proposed by the National Center for Disaster Prevention (CENAPRED)

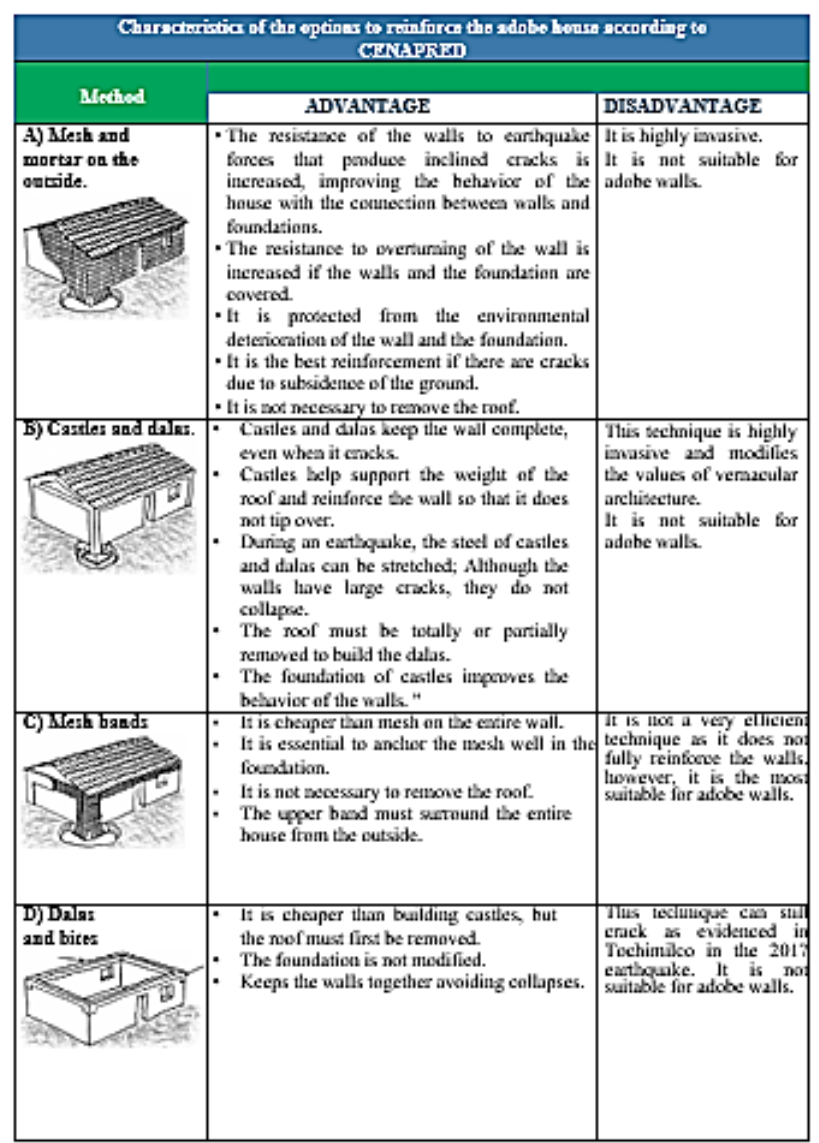

Figure 5 Comparison of options to reinforce the home Source: Vázquez, 2018 with information from CENAPRED, $s / f$.

The most effective techniques for adobe constructions are the traditional ones both to make the block and the mortars that are used for its repair. However, the most used material is high-purity lime due to its adherent qualities, compatibility and resistance, which is used for injection of cracks and fissures or for grouting (Díaz, 2007).

The consolidation of adobe walls through the injection of whitewash reduces structural cracks. Structural cracks can significantly decrease the stiffness and strength of walls, increasing the risk of collapse during new earthquakes. Therefore, traditional building rehabilitation methods seek to increase resistance through the demolition and replacement of cracked walls. In the case of historical constructions, these techniques are invasive and cause the deterioration of the patrimonial value; Therefore, current damage repair systems seek stability through tensileresistant reinforcements. However, the international conservation community does not agree with these techniques as it modifies the originality of historical monuments. 
Vargas and Neumann (2010) carried out laboratory tests on repairing structural cracks in historical adobe buildings and reached the following conclusions that favor the consolidation of adobe walls through the injection of grout. It is a viable alternative, to improve the resistance of adobe walls, the repair by injection of mud grouts without stabilizers was effective to recover the resistance of the walls. Good quality of the injection process is important for effective repair.

It was also observed that the stabilization of mud mortars by adding cement and lime did not produce good results. Gypsum was the best of the stabilizers studied, but made repair difficult. The screened mud grouts exceed the original strength, but increase the stresses of the adobe wall with the consequent appearance of cracks. The less thickness of the mortar, the greater the resistance of the masonry; Therefore, the lesser thickness of cracks and grout, a more effective repair will be obtained. There is a need to study the penetrability and control of microcracks with natural additives and processed additives, as well as their mechanical and physicochemical characteristics.

A common practice is the physical replacement of the damaged areas by mortars with pure lime. It is a process where the material is removed from the joints or from the adobe by bulging or alteration of the material, and it is replaced with new material. It is intended to restore the load capacity, for which the same material is used, however, in practice different materials are placed that modify the bearing characteristics of the construction elements.

Grouting is a process for the consolidation of buildings in areas of seismic activity that consists of injecting a binder of liquid consistency to fill gaps, pores and fissures. This system allows the adhesion of disaggregated particles, recovering its mechanical capacity to absorb the stresses of the wall. Injection systems must have a staggered arrangement of injection holes of 2 to 4 holes per $\mathrm{M}^{2}$ (staggered is a system where an equilateral triangle is formed by determining the distances beforehand). When using cementitious grouts it is necessary to control the water-cement ratio as it can affect the fluidity of the grout injection; the lower the water-cement ratio, the greater the strength, compactness and durability of a conglomerate, but this also means less fluidity and, therefore, less injectability (Aguilar, 2016).
On the other hand, the difficulty involved is determining the real absorption of each wall and its hydration, since the degree of humidity required is variable; It is common to reduce the water-cement ratio to the maximum, but there is a risk that the grout is not liquid enough to penetrate the wall.

The calcareous composition grouts are best valued by conservators and restorers for their affinity of chemical and mineralogical composition with the mortars of the old factories, for their high relative elasticity that allows them to adapt to the movements of these buildings, for their high porosity as they react very well before salt crystallizations. It is currently used for the manufacture of special macro porous mortars for coatings to absorb moisture and evaporate it without damage due to salt crystallization and without causing barriers or displacement of the usual humidity in historic buildings. As for its great chemical stability, it intensifies with time, due to its lack of soluble salts that can migrate to other elements, crystallizing, affecting the elements of the building; However, there is the difficulty of carbonation of the aerial limes inside the factories due to lack of aeration. Currently it is used for the manufacture of special macro porous mortars, for coatings that allow the absorption of humidity, whose evaporation does not leave damage due to salt crystallization. As for cementitious grouts, they have the advantage of their injectability, which is favored by the use of superplasticizers to reduce the water necessary for their workability and resistance capacity. There are problems with polymeric grouts due to the lack of security regarding their long-term mechanical or chemical behavior (Aguilar, 2016).

Astorga (2011), states, that the grout injection technique to seal cracks, the biggest problem is the penetrability of the liquid mud because the smaller the thickness of the crack, the more fluid it should be applied and binds fewer particles of the adobe. In the tests carried out by experimental historical sites in Lima, he observed that the relationship between the speed at which cracks are created and the speed of drying was variable in the formation of cracks. Therefore, it determined a lower drying speed, the lower the number and thickness of the cracks. After observing the good performance of these methods, we opted for the technification of injection procedures.

CASTILLO-REYES, Alberto Rosendo, VÁZQUEZ-TORRES, María del Rayo, MORALES-ORTEGA, Alejandro and MONTEROURRUSQUIETA, Rubén Ángel. Materials for the intervention of construction systems for adobe housing. Journal of Scientific and Technical Applications. 2020 


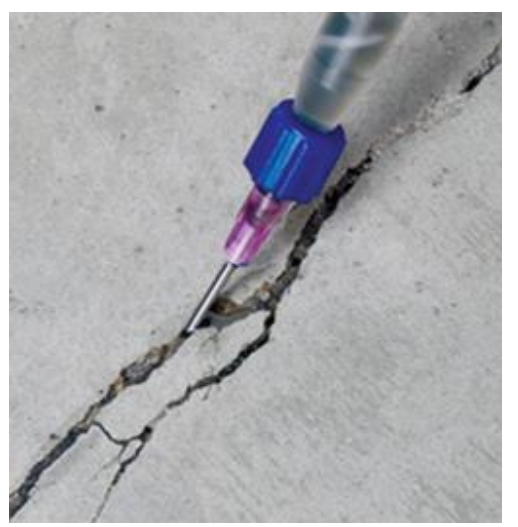

Figure 6 Grout injection in adobe walls in historic buildings

Source: (Astorga, 2011)

The process to consolidate adobe walls according to Rehabimed, (2007); Astorga, (2011) and Autoconstructor (2014), stated that it is necessary to stabilize the area so that movements in the wall do not occur, since subsequent movements will be more difficult to solve after the grout is injected inside the wall.

Also, the cleaning of the facing will be with a pickaxe and a wire brush to remove the remains of old mortars from the surface and joints of the adobes around the cracks; This facilitates the application of the grout and the adhesion between the adobe and the mud mortars or the injection of the grout. In the event that the wall has plaster and sounds hollow, it must be considered that there is a loss of adhesion and a detachment of the plaster, it will be necessary to clean the surface.

Regarding the injuries, they indicated that they are produced by points of humidity and it will be necessary to verify that the entrance of humidity is solved and proceed to repair the affected areas before the new application; If the damage is due to a poor adherence of the plaster to the support, due to insufficient evaporation of the water contained in the walls, a total repainting of the plaster will be necessary and it must be replaced by a natural lime mortar, which allows the breathing of walls and waterproofs them.

When you want to rehabilitate a wall with a plaster in good general condition, you must check that it is well adhered to the masonry and if it sounds hollow in any area you must remove the material and apply a localized injection. It is important to check the cohesion of the mortar, rubbing the surface with strong pressure.
For the preparation of the lime slurry, an electric mixer is of great help, a very fluid water and lime based slurry to be able to inject it through the pipes, filling the interior of the wall.

The preparation of the joint begins with cutting the damaged section until a regular bottom is obtained, using oblique blows with gradines or toothed chisels, chisels, pointers or micro lathes.

The loose fragments are cleaned with a brush and a jet of water, taking care not to unnecessarily saturate the wall, doing it up and down to completely remove the dust. The mortar for the joints must be less resistant than the original, so as not to modify the characteristics of the internal stress state of the wall.

To be able to exert the pumping pressure, an outer coating that works as a mold or with temporary sheets of soluble gels based on silicates such as carboxymethylcellulose or cementitious is needed. It should be noted that this process presents problems when the wall has wall paintings where detachment of this layer or filtration of the grout may occur.

To form the formwork, the crack must be superficially sealed with mud and straw mortar, to contain the grout inside the wall. The crack must be covered and embedded pipes are left directed towards the interior of the wall to be able to inject the grout. The tubes will be spaced between $30 \mathrm{~cm}$ to $40 \mathrm{~cm}$, keeping the funnels on the wall until the grout fills the gaps.

The tube will be slowly removed, taking care that the grout decreases its level and if necessary, inject more lime mixture into the tube. When finished, the hole will be covered with a fresh mixture of mud, sand and straw.

In the event that the adobe wall has a thickness where the gaps cannot be covered with grout, it must be injected on both sides of the wall. It is not necessary to let the mortar dry too much because the lime used has hydraulic properties and hardens in humid environments, it should be considered that it lacks air inside, so the milk of lime will dry slowly. 
The whitewash and water must be allowed to dry before subjecting the walls to any stress for at least a month, it will not be excavated nearby so as not to dislodge the wall and cause cracks, since lime hardens more slowly than mixtures with cement. Hydraulic lime has the ability to harden in humid environments and this is very useful for these types of repairs.

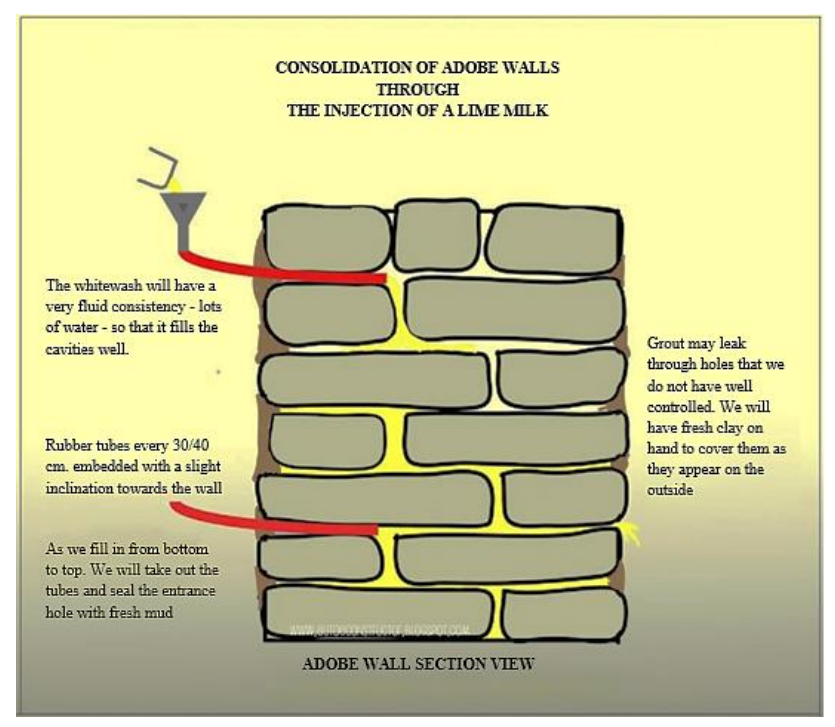

Figure 7 Consolidation of adobe walls by injection of whitewash

Source: (Autoconstructor, 2014)

In the case of ceilings, it is common for the beams to be damaged by moisture and replacement is necessary.

As for ceilings, the application of the technique by functional substitution of beam supports is common. The resistant supplements in beams and joists is the application of new flexural elements to absorb the efforts that the beams must withstand that are greater than their resistance. Wood connections or steel profiles are used, in different positions.

Its handling depends on the design conditions; that is to say, the upper position is used when for aesthetic reasons or due to the existence of architectural elements it is convenient that they are not seen. The lower position is the most common for ease of connection and the lateral position is used as reinforcement of wooden beams that support heavy weights (Figure 8).

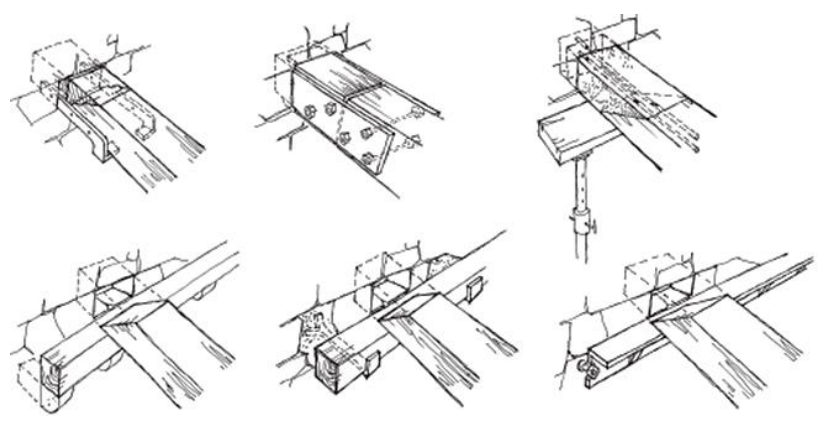

Figure 8 Functional or reinforcement replacement in the supports affected by the decomposition of the wood Source: (Diaz C., 2007, p. 303)

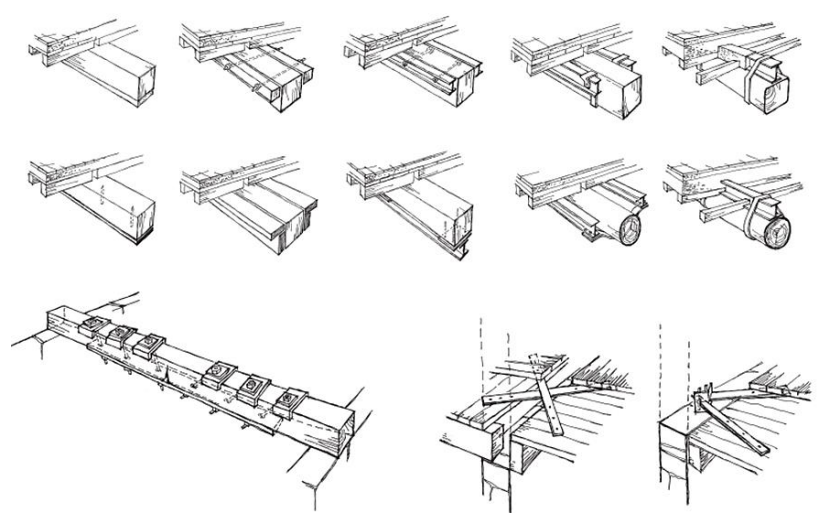

Figure 9 They are built with two elements joined with anchor bolts through reinforcing the beam Source: (Díaz C., 2007, p. 304)

Mullions are used to reduce bending stresses in overloaded beams, wooden or steel beams placed transversely to the existing beams are used to divide the spaces, as long as there are good support conditions. wooden beams; a beam is placed in the long sense of the house-room, and secondary beams in the short sense.

It is a system that has been used in Tochimilco, Puebla, especially in historic buildings, during the 2017 earthquake it was verified that the load concentrated in the center of the wall caused cracks due to the weight and the lack of adherence of the mortar caused by the demolition of the area where the beam was placed. Although in Tochimilco there are few buildings with wooden roofs with gabled slopes; it is common that the weight is not distributed evenly, causing significant flexing or breaking in the shorter walls. This situation is amplified by the spaces left by windows (some houses have a small window of $0.40 \mathrm{~m}$. X $0.40 \mathrm{~m}$ ) and doors, it generates a concentration of efforts, which can lead to shear or bending cracks in the walls. It is also observed in Tochimilco that wooden lintels are placed that improve the behavior of the adobe walls. 
The buildings in Tochimilco are affected by weather events and the deterioration they produce. The deterioration of the materials of walls and ceilings, modify their structural behavior and are more vulnerable to earthquakes. Moisture is one of the great problems of constructions and in the case of adobe constructions it occurs due to the infiltration of water through the roof, walls and foundations.

\section{Conclusions}

The houses in the Mexican Republic have elements in common and the modifications are to solve weather problems and conditions of the land where they are built, causing the loss of resistance due to external actions and dimensional variations. However, because it is an architecture of the people and for the people, institutions such as the Public Administration of Mexico City and ONNCCE do not contemplate a regulation for adobe masonry, although the general specifications are applied.

The biggest problem observed in the Popocatépetl area is the humidity that has deteriorated the adobe in different ways, up to the sandblasting or pulverization, for which the adobe is seen as a vulnerable material.

This issue requires greater dissemination within university fields to awaken interest in this type of construction that allows its conservation and permanence as it is part of the construction tradition.

\section{References.}

Administración pública de la ciudad de México. (2017). Gaceta oficial de la Ciudad de México. México: Órgano de Difusión del Gobierno de la Ciudad de México.

Aguilar, A. (2016). Consolidación estructural de fábricas: rejuntado, inyección y armado, Máster universitario en construcción y tecnología de los edificios históricos . Madrid: Escuela Técnica Superior de Arquitectura de Madrid.

Asociación Colombiana de ingeniería sísmicaAIS. (2004). Manual de rehabilitación de viviendas construidas en adobe y tapia pisada. Bogotá: Presidencia de la República de Colombia; Red desolidaridad social .
Astorga, S. (2011). ANÁLISIS DEL COMPORTAMIENTO DE MUROS DE ADOBE REFORZADOS CON GEOMALLA ANTE ESFUERZOS CÍCLICOS LATERALES. Sevilla: UNIVERSIDAD DE SEVILLA.

Autoconstructor. (15 de enero de 2014). Consolidación de muros de adobe mediante la inyección de lechada de cal. Obtenido de http://autoeconstructor.blogspot.com/2014/01/c onsolidacion-de-muros-de-adobe.html

CENAPRED. (s/f). Cartilla breve para refuerzo de la vivienda rural de autoconstrucción contra el sismo y viento. México: Coordinación General de protección civl.

Díaz, C. (2007). La rehabilitación de los elementos estructurales de la arquitectura tradicional mediterránea. En X. Casanovas, Herramienta 8 Las técnicas de rehabilitación: reforzar las estructuras (págs. 297-308). Barcelona: RehabiMed, Unión Europea, EUROMED, EUROMED Heritage, Agencia española de cooperación Internacional y Colegio de arquitectos técnicox de Barcelona.

Gisbert Nieto, A. (2020). El adobe, una oportunidad de desarrollo sostenible para la región ixil: Proyecto para la recuperación de técnicas tradicionales de construcción en las comunidades de Nebaj, Guatemala.

González, R., Aguilar, J., \& Gómez, C. V. (2008). Sociedad Mexicana de Ingeniería Estructural, vulnerabilidad de viviendas de adobe en Chiapas y alternativas de reparación. Veracruz: SMIE, XVI Congreso Nacional de Ingeniería Estructural.

Guerrero Baca, L. F. (2008). ICOMOS informe mundial 2006/2007 sobre monumentos y sitios en peligro. MEXICO: La pérdida de la arquitectura de adobe en México. En ICOMOS, HERITAGE AT RISK, Patrimonio en Peligro (págs. 112-114). Alemania: Published by E. Reinhold-Verlag, Altenburg.

Juárez, H., Gómez, A., \& Sordo, E. (2002). Recomendaciones para reducir la vulnerabilidad sísmica de estructuras de mampostería. México: Universidad Metropolitana. 
Larrota Meza, M. E., \& Roa Granada, M. R. (2020). COBEPLAC construcciones en adobe para las comunidades de recursos limitados.

Lefevre, R., \& Lilian, C. (2016). Estructuración de Cubiertas de Madera y accesorios. Construcciones de Madera y de Hierro. México: Instituto Politécnico.

López Pérez, C., Ruiz, D., Jérez, S., Quiroga, P., Jairo, U., \& Edgar, M. (2007). Rehabilitación sísmica de muros de adobe de edificaciones monumentales mediante tensores de acero. APUNTES vol. 20, núm. 2 (2007): 304-317, 304378.

Losa, N. R., Spina, M. L., \& Cabrera, S. (2020). Restauración de la Casa del brigadier López. Santa Fe, Argentina. Gremium, 7(14), 125-136

Monjo, J., \& Maldonado, L. (2001). Patología y técnicas de intervención en estructuras arquitectónicas. Madrid: Escuela de Arquitectura de Madrid.

ONNCCE. (2015). Normas técnicas complementarias para diseño y construcción de estructuras de mampostería. México: ONNCCE.

Peña M., F., \& Lourenço, P. (2012). Criterios para el refuerzo antisísmico de estructuras históricas. Revista de Ingeniería Sísmica No. 87 47-66 (2012), 47-66.

Ramírez, M. Á. (2011). Deterioro y estabilización del adobe. México: Instituto politécnico Nacional.

Vargas-Neumann, J. e. (Septiembre de 2010). Obtenido de "Uso de grouts de barro líquido para repasar fisuras estructurales en Arquitectura de Tierra en Cuenca de Campos 2004/2009. [online]. Valladolid: Cátedra Juan de Villanueva.:

http://www5.uva.es/grupotierra/publicaciones/d igital/libro2010/2010_9788469345542_p281-

288_vargasneumann.pdf 